Journal of Teacher Education for Sustainability, vol. 18, no. 1, pp. 127-139, 2016

\title{
Social Equality as Groundwork for Sustainable Schooling: The Free Lunch Issue
}

\author{
Brigita Kairiene and Andrius Sprindziunas \\ Mykolas Romeris University, Lithuania
}

\begin{abstract}
The purpose of the present study was to discuss the way of organizing free lunch at public schools as an important precondition for social equality and sustainability in school, by revealing acute forms of social disjunction in Lithuanian schools as a major incongruity with Children Rights, and an obstacle to the achievement of general education goals. The objective of the study: to study the experience of pupils subject to free lunch in public schools, as well as the experience and viewpoints of pedagogues involved in the organization of free lunch in relation to social equality and sustainable schooling.

A qualitative research was conducted in several Lithuanian schools focusing on the experience of the pupils, who had the privilege of having cost-free lunch at schools, as well as the pedagogues involved in organizing free lunch. The research data indicated the violation of children's rights to healthy nutrition, as the respondents complained about the quality and the way of implementation of free lunch in schools. The research data revealed some discriminatory practices of separate queues to provide dishes to pupils from needy families, and limited or lacking opportunities for them to choose dishes. The analysis of the research data led to the recommendation to professionally assess the correspondence of the organization of free meals in the aspects of effectiveness, legal regulation and ethics with children's needs.
\end{abstract}

Keywords: free lunch, children's rights, pupils, public school, children from needy families, nutrition, social equality, sustainability

\section{Context of the Study}

Problems of social equality are common in every society, and public school is a special institute where educative experiences bring together people of various social origin and life circumstances. Although a specific element of school life, having lunch and other meals at school is related to children's vital nutritionals needs and thus should be treated as one of the basic descriptors of the social environment of a school. On pragmatic grounds, J. Dewey has paid special attention to the educative role of school environment and social experience: "We never educate directly, but indirectly by means of the environment. Whether we permit chance environments to do the work, or whether we design environments for the purpose makes a great difference" (Dewey, 2013, p. 16). 
In the second half of the $20^{\text {th }}$ century a significant progress was achieved in public education theory and practice. Discussing the sustainable school in the contemporary context of Western culture, W. Scott (2013) has addressed social issues among the essential descriptors of the eco-restorative vision of the future good school and sustainable education, including communication, wealth, self-realization, self-respect and happiness. It is noteworthy, that evident effect on educational outcomes was fixed in some countries after radical reform in provision of meals at schools (Belot, James, 2011), and positive progress of class behaviour achieved after the modification of dining rooms (Storey et al., 2011). Then some experts of relevant educational vision have emphasized equity as the central object of focus in discussing any question of what the best practices of teaching are (Nilson, 2010).

Education management in the countries of the European Union must correspond to the recent flagship initiatives of "EUROPE 2020" strategy for smart, sustainable and inclusive growth. It is crucially important that the "European platform against poverty" is implemented; its goal is to ensure social and territorial cohesion so that the benefits of growth and jobs are widely shared and people experiencing poverty and social exclusion are enabled to live in dignity and take an active part in society (Communication from the Commission. EUROPE 2020, 2010). With reference to national traditions and current national topicalities, the recommendations of the experts of European Commission should not be neglected by the authorities of the European countries, especially because comparative statistical surveys have revealed some critical deficiencies among respondents of school age.

For instance, Lithuania was identified as number one in prevalence of peer jeer, the highest rates of teenagers' suicide and the least percentage of happy children (Bradshaw, Hoelscher, Richardson, 2007; Patyčios Lietuvos mokyklose: problemos ir jų sprendimo būdai, 2009). A representative survey of discrimination in Lithuanian schools in 2009 revealed evidence of discrimination on grounds of social position. In particular, it found peer isolation of the students who came from poor families (Jonutyte et al., 2009). The same survey revealed the tendency of students coming from more wealthy families to sneering and jeering at or ignoring students coming from less wealthy families.

The alarming data on the Lithuanian children's condition led to corresponding administrational efforts and practical initiatives of educators and authorities. Special endeavour to reduce social exclusion was incorporated in the strategic Lithuanian national documents (Lithuania's Progress Strategy “Lithuania 2030”, 2012). National documents on education emphasized the need to create an effective system of social assistance for disadvantaged participants in the educational system (State Strategy for Education 2013-2020, 2013). The frame of the strategic goals led to development of a new learning environmental model with a new emphasis on the whole of learning and experience. The most important feature of a successful school performance is considered to be the appropriate implementation of the school's mission, i.e. good (desirable, acceptable) educational outcomes and rich, memorable, meaningful, pleasurable school life and learning experiences. Following the concept of good school, new learning environment models have become especially important, for example, the model of personality development for value orientations - a person's social, civil, and moral maturation (Geros mokyklos koncepcija, 2015).

In practice, these objectives of the "good school" are yet to be reached because there is a discrepancy between the conceptual flagship and its realization. The gap 
between the high standard values declared in the official schooling programs and the common practice in schools has been spotlighted by some researches (Cohen, et al., 2009).

One of the best models of sustainable schooling, including a progressive model of meals in public schools can be found in Finland, where free lunch for every pupil is set in the national laws and recognized as an investment in the future, as an important precondition to healthy society, good learning achievements, social solidarity and, in general, as a guaranty that everyone has equal access to education (The Basic Education Act (628/1998), 2010).

After joining the United Nations Convention on the Rights of the Child in 1992, Lithuania accepted the obligation to put all its efforts to guarantee the protection of the children's rights (Convention on the Rights of the Child, 1989). The convention recognized the inalienable right of every child to live, grow, be healthy and have living conditions necessary for his or her physical, mental, spiritual, moral and social development. Parents or other persons responsible for the child have the primary responsibility to secure the conditions of living necessary for the child's development but, in case of limited abilities and parents' financial capacities of, the state party shall take the appropriate measures and shall provide material assistance and support, particularly with regard to nutrition, clothing and housing (Convention on the Rights of the Child, 1989).

Despite national and international efforts to protect and promote the rights of the child, the situation of children in Europe and around the world is yet far from satisfactory. Ombudsperson for Children's Rights of the Republic of Lithuania has officially reported national poverty rates varied from 22 to 27 per cent (Comment of the Ombudsperson for Children's Rights of the Republic of Lithuania..., 2012), while the latest national statistics provided slightly lower rates, close to 20 per cent.

The UN Committee of Child Rights in the General Comment No. 15 on the right of the child to the enjoyment of the highest attainable standard of health noted a special importance of provision of adequate nutritious foods for the children. The need to ensure all pupils to a full meal every day is emphasized, along with the efforts to enhance children's attention for learning and increase school enrolment (Committee on the Rights of the Child, 2013).

In a similar way, the importance of appropriate nutrition has been recognized by many researches as one of the basic preconditions for physical, mental and emotional development, as well as successful learning (Szczepańska, Deka, Calyniuk, 2013). Because of the need for intense scheduling and continued duration of four to eight hours at school, plus the time spent by pupils on the way to the school and back home, school meals must be considered an important part of pupils' whole day ration. That is why school meals must be complete and sufficient. School lunch is expected to satisfy one third of pupils' daily ration (Finnish National Board of Education, 2008; Kupiainen, Hautamäki, Karjalainen, 2009).

Legal acts of Finland set the obligation for every municipality to draw up a plan for pupils' welfare. A well-balanced meal for each pupil every school day is one of the main attributes of national system of education in Finland, ensuring that everyone has equal access to education in both declarative and practical ways. Educational model in Finland has evidently made an impact on other North European countries, for instance, Sweden, Estonia, Latvia, UK and some others to adapt similar practices of free meals for all or for some of pupils of public schools. In a similar way, school policies are grounded on children's need of healthy nutrition, social equality and sustainable schooling. 
As a developing democracy with a developing economy, Lithuania has adopted basic European legal norms in relation to human rights, and with this adoption there can be no excuses like economical deficiency or lack of funds for schools to guarantee the rights of children to healthy nutrition and personal dignity. Therefore, institutions of the Republic of Lithuania put their best efforts to follow the general provisions of the Convention of the Rights of the Child, UN Committee of the Rights of the Child as well as adopting the best practices of other European countries.

In Lithuania, the State is ready to provide its support for every child from needy families (Republic of Lithuania Law on Fundamentals of Protection of the Rights of the Child, 1996). Following the Republic of Lithuania Law on Social Assistance for Pupils, pupils shall have the right to free meals and to the assistance in purchasing school supplies if the average monthly income per one of the persons living together or single person (hereinafter referred to as "average income per person") is less than 1.5 amounts of the state-supported income (Republic of Lithuania Law on Social Assistance for Pupils, 2006).

Human rights and equal treatment of every person is an undeniable standard in democratic Western societies. Specifically, the rights of children unquestionably must be observed, with the continuing efforts to implement the best practices in juvenile institutions. With the rising interest in the nutritional quality of food in schools in respect to students' health, quite unintentionally the problem of human dignity and children's rights emerged. This problem was discovered during the recent investigation of the experience of pupils and their teachers, particularly related to organizing free lunch served in public schools of Lithuania.

The purpose of the present study was to discuss the way of organizing free lunch at public schools as an important precondition for social equality and sustainability in school, by revealing acute forms of social disjunction in Lithuanian schools as a major incongruity with Children's Rights, and an obstacle to the achievement of general education goals.

Objective of the investigation: to study the experience of pupils subject to free lunch in public schools, as well as the experience and viewpoint of pedagogues involved in the organization of free lunch in relation to social equality and sustainable schooling.

\section{Participants and Procedure}

A qualitative research method was chosen as the most relevant for obtaining the data about the experience of pupils, who were privileged to receive free lunch, as well as about the experience and attitudes of their pedagogues involved in the process of organizing free lunch, as well as the issues of social equality in relation to sustainable schooling. There were not enough reliable data about peculiarities of organizing free lunch in public schools and pupils' experience in Lithuania, and therefore a new investigation was needed.

Participants. The investigation was carried out in five randomly selected schools in Vilnius city, Kaunas city and Vilnius area. A selective criterion for the identification of respondents was applied because the research was focused on the respondents' specific experience, rather than on the experience of any random pupil or teacher. Therefore, it was important to select respondents who had experienced the phenomenon under study. They were students of public schools of ages 11 to 15 , who enjoyed the free lunch 
program in their schools, and pedagogues who were responsible for organizing meals in their schools.

The research participants were interviewed to achieve informational redundancy (Bryman, 2012). The volume of the sample was nine pupils and six pedagogues when no new information was received from them (Table 1).

Table 1

The Research Sample

\begin{tabular}{|c|c|c|c|c|}
\hline Informant & Number & Age (years) & Sex & Locality of the school \\
\hline \multirow[t]{9}{*}{ Pupils } & $\mathrm{I}-1$ & 11 & $\mathrm{M}$ & Vilnius city \\
\hline & $\mathrm{I}-2$ & 11 & $\mathrm{~F}$ & Vilnius city \\
\hline & $\mathrm{I}-3$ & 11 & $\mathrm{M}$ & Vilnius city \\
\hline & $\mathrm{I}-4$ & 14 & $\mathrm{M}$ & Vilnius district \\
\hline & $\mathrm{I}-5$ & 14 & $\mathrm{~F}$ & Vilnius district \\
\hline & $\mathrm{I}-6$ & 15 & $\mathrm{M}$ & Vilnius district \\
\hline & $\mathrm{I}-7$ & 15 & $\mathrm{~F}$ & Vilnius district \\
\hline & $\mathrm{I}-8$ & 11 & $\mathrm{~F}$ & Vilnius district \\
\hline & $\mathrm{I}-9$ & 11 & $\mathrm{M}$ & Vilnius district \\
\hline \multirow[t]{6}{*}{ Pedagogues } & II-1 & 42 & $\mathrm{~F}$ & Vilnius district \\
\hline & II-2 & 37 & $\mathrm{~F}$ & Vilnius district \\
\hline & II-3 & 53 & $\mathrm{~F}$ & Vilnius city \\
\hline & II-4 & 48 & $\mathrm{~F}$ & Vilnius city \\
\hline & II-5 & 26 & $\mathrm{~F}$ & Kaunas city \\
\hline & II-6 & 49 & $\mathrm{~F}$ & Kaunas city \\
\hline
\end{tabular}

The interviewing was realized in January - February 2015. Prior to the investigation, the permissions of school administration and parents of the selected pupils, as well as the respondent children's consent were received. With the respondents' agreement, the interviews with them were recorded using a Dictaphone. The interviews with pupils were coded as I-N, and interviews of pedagogues - as II-N.

The qualitative investigation was focused on the question of whether lunch in public schools corresponded to the need for meals of the pupils from less wealthy families, and how the need for such meals was organizationally met.

The method of semi-structured interview was chosen as the most relevant and two different interview guides were designed to interview the pupils and the pedagogues (Table 2).

Table 2

The Interview Topics

\begin{tabular}{ll}
\hline \multicolumn{1}{c}{ Interview guide for: } & \multicolumn{1}{c}{ Interview topics } \\
\hline pupils & Relations with peers \\
\cline { 2 - 2 } & Relations with teachers \\
\cline { 2 - 2 } & Meals at school \\
\hline teachers & Meeting pupils' physiological needs for nutrition at school \\
\cline { 2 - 2 } & Subjective value of free lunch \\
\cline { 2 - 2 } & Social justice \\
\hline
\end{tabular}


The method of qualitative content analysis (Berg, 2007) was applied to analyse the data collected. The transcriptions of the interviews were read several times with the purpose to extract important statements that were directly related to the respondents' experience. Those statements were then grouped and transformed into several themes and subthemes for reliable interpretation.

The research ethics. The investigation was conducted according to the requirements of the social research ethics: the respondents were informed about the objectives and the contents of the survey, confidentiality was kept to preserve their personal data and voluntary participation was guaranteed by asking for personal consent to be interviewed with the possibility to withdraw from it at any moment.

\section{Research Findings}

The central aim of the data analysis was to reveal and categorise the experience of the pupils who were subject to free lunch at school. Due to the limits of the present article there were no possibilities to display the full framework of the research with all the variety of subthemes as it was revealed in the process of content analysis. Therefore, the scope of the social equality led to a special focus on some of the themes, especially the ones related to children's basic nutritional needs, as well as common social standards of the school community.

First, a positive evaluation of free meals in school was abstracted, as both pupils and their teachers spoke about the importance to satisfy the nutritional needs of everybody, and those of children from less wealthy families in particular. Then the combination of subthemes like "long queues", "duration of the break", "unfriendly behaviour of other (or the older) pupils" led to the formulation of the first problem related to the availability of meals for pupils in school (Table 3).

Table 3

Availability of Meals

\begin{tabular}{|c|c|c|}
\hline Theme & Pupils & Pedagogues \\
\hline $\begin{array}{l}\text { Availability } \\
\text { of meals } \\
\text { in school }\end{array}$ & $\begin{array}{l}\text { "It takes long to wait in } \\
\text { the common queues, the } \\
\text { older students come straight } \\
\text { to it <...> it happened } \\
\text { recently that I had to leave } \\
\text { it hungry and nervous (I-1). } \\
\text { "Today I was not able to } \\
\text { eat as the queue was very } \\
\text { big, it takes long to serve } \\
\text { everyone" (I-2). } \\
\text { "It's a common queue <...> } \\
\text { it's enough time to eat only } \\
\text { if our teacher allowed us to } \\
\text { leave earlier" (I-5) }\end{array}$ & $\begin{array}{l}\text { "It's not good that they all come during the only } \\
\text { long break which takes } 20 \text { minutes. There are } \\
\text { many children, they have to eat fast, and it is not } \\
\text { healthy to eat fast. Probably, not everyone has } \\
\text { enough time to eat" (II-3). } \\
\text { "It's alright because there are children from poor } \\
\text { families and they can get meals. Those who are } \\
\text { from the poorest families probably consume } \\
\text { everything that is served, in addition also what } \\
\text { has been left uneaten by a friend <...> there are } \\
\text { children who don't attend their classes, are ill, } \\
\text { but they come for lunch and then leave" (II-4) }\end{array}$ \\
\hline
\end{tabular}

In general, every pupil respondent complained about the way of organizing meals at school and their remarks were endorsed by the pedagogues, who expressed similar criticism concerning the organization of school meals and the free lunch program in 
particular, recognizing that pupils lack time for their meals. It led to the identification of the problem of an insufficient availability of meals for pupils as they were not guaranteed the necessary time for meal during the lunch break. A further analysis of the problem would lead to the inquiry of the practices of organizing meals in schools and the causes preventing the possibility for every child to have lunch.

Another major problem identified during the research was that of the lack of the dish choice for students who were the users of the free lunch service in their schools. It led to the formulation of the next theme (Table 4).

Table 4

Possibility to Choose Dishes

\begin{tabular}{|c|c|c|}
\hline Theme & Pupils & Pedagogues \\
\hline $\begin{array}{l}\text { Possibility } \\
\text { to choose } \\
\text { dishes for } \\
\text { free lunch }\end{array}$ & $\begin{array}{l}\text { "There are three parts of lunch. You } \\
\text { are allowed to choose only the drink. } \\
\text { If you wish something else - you need } \\
\text { to pay" (I-1); } \\
\text { "I have no choice of dishes" (I-2); } \\
\text { "No choice" (I-3); } \\
\text { "I get it for free, therefore I eat what } \\
\text { they serve" (I-4); } \\
\text { "You can't choose if you take it for } \\
\text { free, you can choose only if you pay" } \\
\text { (I-5); } \\
\text { "There is no choice" (I-6); } \\
\text { "Having a choice would be great. My } \\
\text { classmates, who do not receive free } \\
\text { lunch, get much more delicious dishes" } \\
\text { (I-9). }\end{array}$ & $\begin{array}{l}\text { "There is no choice for the children } \\
\text { who receive free lunch - usually there } \\
\text { are dishes served which match their } \\
\text { price" (II-1); } \\
\text { "Children can't choose. Just there is a } \\
\text { variety of one dish one day and another } \\
\text { dish on the next d <..." (II-2); } \\
\text { "Differentiation, a choice of dishes } \\
\text { would be an advantage in organizing } \\
\text { meals." (II-3); } \\
\text { "<...> of course, it would be better if } \\
\text { they could pick some products what } \\
\text { they wish, as it is in some restaurants, } \\
\text { or hotels, where they can choose. Pupils } \\
\text { love that." (II-3). }\end{array}$ \\
\hline
\end{tabular}

The problem of the possibility to choose dishes was evident in all of the schools considered. All the respondents, both pupils and pedagogues, indictedthe problem and only minor choice of dishes with supplements or beverages was noticed in some of the cases. Seemingly, pupils of smaller schools had no choice of dishes at all, as there was only one option of every dish on a particular day, and another for the next day, according to the earlier scheduled menu for those who were using free lunch tickets. The pupils' complaints concerning free lunch were confirmed by the teachers who noted that at the same time there was a good choice of dishes to buy.

The next theme was related to the subjective assessment of food quality by the pupils and the pedagogues (Table 5).

The content analysis revealed a range of subjective assessments from "delicious" to "tasteless" and even "disgusting". Pupils told which products and dishes they never ate, they also complained that portions were small and they still felt hungry after lunch. While teachers were mostly concerned about some good-looking products left uneaten and likely hungry children because meals in school did not correspond to their eating habits and dishes they ate at home.

Basically, one may notice a relation between the possibility to choose a dish and the subjective assessment of the taste of dishes as both of them attribute to the same issue of the quality of food service in school. Every child is an individual and one's individual taste may only be pleased if there is a choice of dishes. 
Table 5

Quality of Dishes of Free Lunch

\begin{tabular}{|c|c|c|}
\hline Theme & Pupils & Pedagogues \\
\hline $\begin{array}{l}\text { Subjective } \\
\text { assessment } \\
\text { of the quality } \\
\text { of dishes of } \\
\text { free lunch }\end{array}$ & $\begin{array}{l}\text { "It's delicious" (I-2); } \\
\text { "Everything is delicious with excep- } \\
\text { tion of cutlets" (I-3); } \\
\text { "Today they gave cabbage - I don't } \\
\text { eat cabbage. I don't like cutlets" (I-4); } \\
\text { "They serve it delicious, but too small. } \\
\text { Sometimes it's, for instance, mush- } \\
\text { room soup. I don't like mushrooms. } \\
\text { Then I don't eat." (I-7); } \\
\text { "There are my classmates who are } \\
\text { very dissatisfied - the portions are too } \\
\text { small or food is not delicious" (I-8); } \\
\text { "Pancakes happen to be very distaste- } \\
\text { ful <...> I don't eat then." (I-9). }\end{array}$ & $\begin{array}{l}\text { "It happens that they don't eat some } \\
\text { dishes, in fact, they just drink compote, } \\
\text { very often they refuse to eat soups, } \\
\text { then soups are left on the tables, if } \\
\text { children don't like <...>" (II-1); } \\
\text { "I assess it as good <...> we serve it } \\
\text { qualitatively, it's delicious and } \\
\text { various." (II-2); } \\
\text { "Children don't eat the food, we } \\
\text { don't know what the children eat at } \\
\text { home, and we seriously need to find } \\
\text { out what they eat at home. They leave } \\
\text { the food and it's a pity <...>" (II-4). }\end{array}$ \\
\hline
\end{tabular}

Finally, the problem of social equality and human dignity contravention emerged in the situations of providing pupils with free lunch at schools (Table 6).

Table 6

Social Equality Facet

\begin{tabular}{|c|c|c|}
\hline Theme & Pupils & Pedagogues \\
\hline $\begin{array}{l}\text { Unequal } \\
\text { opportunities } \\
\text { and the sense } \\
\text { of human } \\
\text { dignity }\end{array}$ & $\begin{array}{l}\text { "My classmates, } \\
\text { who do not receive } \\
\text { free lunch, get much } \\
\text { more delicious } \\
\text { dishes" (I-9). }\end{array}$ & $\begin{array}{l}\text { "What about sneering? There had been cases that } \\
\text { children did not come to get their free lunch tickets; } \\
\text { later we found out that they were ashamed, because } \\
\text { there was a separate queue for those with tickets. Of } \\
\text { course, that is done for effectiveness, to avoid jostle } \\
\text { and feed them faster, but that separation is not good in } \\
\text { the social sense. Younger children do not pay attention } \\
\text { to that, but those at the age of fourteen, the eight- } \\
\text { graders, some of them feel ashamed"; } \\
\text { "They often feel ashamed <...> we encourage children, } \\
\text { we tell them: - "Do not be ashamed, it's a privilege for } \\
\text { you that you receive support, enjoy it!"” (II-3). }\end{array}$ \\
\hline
\end{tabular}

The research did not include direct questions concerning the issue of free lunch aimed at investigating pupils' experiences because of their imparity to their peers who were taking paid lunch. It was a deliberate attempt to not engage pupils' attention to the problem of presumable unequal treatment during their school lunch. Evidently, classmates of the free lunch subject pupils had noticed them passing a special ticket instead of money, standing in a separate queue or sitting by the distinct tables, as it is a common practice in some of the observed schools.

Some of the pedagogues claimed that there was no peer jeer due to the inequality of the pupils during school lunches but some others did acknowledge the problem. In particular, the teachers have attested that some pupils of the higher forms were evidently shy or felt ashamed to use free lunch tickets, kept avoiding picking up the tickets and omitted the lunch time. The current research did not note a particular case of somebody 
becoming a target of peer jeer because of using the free lunch facility in school, but nowise denied it. In fact, the revealed facets of pupils' experience during lunch at school reinforced the suspicion of some faulty practices still existing in the environment of unknown number of public schools in Lithuania.

Further thematic analysis of the research findings on the aspects of social equality and human dignity might lead to the recognition of the problem of ethics, as it has been noticed by some respondent pedagogues.

\section{Discussion}

The research data analysis led to the identification of several problems related to the school lunch practice. The limitations of the study do not allow expanding the findings and to resume about the national public school practice in organizing free lunch but nevertheless, the study identified some children's needs and rights as the issues that need to be discussed.

The quality of meals served in schools has always been what pupil's complain about. Besides, it has always been under an increased control of responsible institutions. But the different service of paid and free meals in public schools, especially the limited choice and practical segregation of peers during lunch leads the discussion to a broader scope of pedagogical, ethical and legal norms.

Following the order of the Health Care Minister of the Republic of Lithuania "On the approval of the inventory of the order of realization of meals in institutions of preschool, general education schools and houses of juvenile social care", it is recommended to ensure a choice of several main hot dishes and several types of garnish for lunch. The research has revealed particular facts of negligence of this recommendation, as quite often there was only one dish for those pupils who were taking free lunch, in contrast to pupils who paid cash. The same problem has also been raised by parents, who were not pleased with meals served to their children who had no choice of dishes. The lack of choice and the necessity to consume unwanted dish served harm the principles of personal individuality and uniqueness, as taste is one of a human's characteristics concurrent to the personal growth.

The practice of segregation of pupils who eligible for free lunch tickets by depriving them of the possibility to choose dishes, and, in some cases, putting them into a separate queues, is presumably discriminative and induces social isolation. Even the use of tickets instead of cash makes the users of free lunch easily recognizable by their peers, and presumably contradictory to their dignity. The Republic of Lithuania Law on Education Article 3.33 states that social care and facilities, provided to children of poor families and thus experiencing social segregation, must be provided with discretion and respect of their dignity, that is, the way of providing social facilities shall not increase discrimination nor make conditions for evident exclusiveness in school or class community. In the case discussed we have observed that manifested by the limited choice of dishes available for pupils from poor families, the use of free meal tickets, which makes them easily recognizable among their peers in the queue and as a physical seclusion if separate queues for poor children are in practice.

It is interesting to note that a similar problem of providing free lunch was observed in public schools in the USA not a long time ago. D. Constantine (2015) has spotted a school case in San Francisco involving the practice of separate queues. One of the queues 
consisted of cash paying pupils, who had the full choice of dishes, and another queue consisted of low-income pupils, who received special pre-packed dietary. Experts evaluated it as a practice of "evident segregation" bringing pupils "back to 50-ties". Separate queues for low income pupils in the sight of their peers were named as "queues of shame" with unhesitating conclusion of stigmatization of pupils in those queues. At the same time consistent facts of "forgetting" to eat the lunch instead of joining the "queues of shame" were observed.

Further investigation revealed similar practice of different queues to realize dietary or free lunch in almost one third of the total number of public schools in the USA!

After the recognition of the separation of pupils who paid and who did not pay for lunch in schools as a contradiction to the Universal Human Rights and laws of the USA, active steps were made to correct the practice. Following experts' recommendations, electronic money was one of the most effective solutions to service everyone in the same queue and to eliminate coloured food tickets for low-income people. The new practice was accepted with enthusiasm by both students and schools personnel. It is interesting to note, that before introducing electronic money in schools, there was a fear of extra expenses and drop of profit in school canteens. But practice demonstrated the opposite, as electronic money made service faster, increased circulation and even enlarged the profit of food supplying companies.

Various and effective practices to avoid discrimination were adopted in Scandinavian schools. In Finland, since early 1940, a law demanded municipalities to provide free lunch for all pupils in schools (Ra'iha et al., 2012). The present law of Finland on Common Education (The Basic Education Act (628/1998), 2010) appoints daily supply of high quality food for pupils of public schools. It is provided free for every pupil in primary schools. For higher grades, various practices have been adopted under the main principle of no discrimination at all, including forms of positive discrimination in favour of pupils from low-income families.

The leading countries, providing free meals for pupils in schools, are Finland, Estonia and Sweden. Some countries have applied practice of free meals in their primary schools (India) and some countries are in the lively process of discussing various models of free meals in schools regarding the social equality issues (like Latvia, UK, USA, etc.). In Lithuania, some national programs of cost-free products for pupils (fruits, milk products) were implemented in primary schools, but the majority of pupils in public schools still encounter typical practices of organizing school meals without proper respect to the needs of the moral and social development of their personality.

Consideration of the implementation of free meals in school as an important element of school life in relation to the children's rights leads to the recognition of disregard of one of the basic principles of the children's rights - the implementation of one right shall not contradict another right. In the case of the present discussion, one may notice that the realization of the child's right to safe environment and healthy nutrition intersects with another fundamental right of any person to be not discriminated.

A child's dignity is absolute and cannot be compromised. Dignity of a child from a needy family cannot be questioned because of social assistance. Every human shares the same dignity and it cannot be diminished by any characteristics of his or her social status, and every child must be equally treated and respected, no matter what his or her social status other social circumstances are. 
Humanism, as one of the basic principles of educational system, is a demand for the recognition of every person's dignity, humane relations with close regard to selfactualization, free choice and responsibility (Pukelis, 1998). Therefore, any effort to provide pupils with social assistance would be meaningless, if it was not grounded on the respect of every child's personality.

In general, only legal, effective and ethical practice can be recognized as good and appropriate. In the case discussed, the ethical controversy is most evident. Even if it was recognized that providing different conditions for children of wealthy and poor families to receive meals in school was legal and effective, because that practice allowed every child to get food and make the process of serving meals faster, still there was the evidence of injustice: pupils were separated into different queues because of the social status of their families, there were minor possibilities to choose dishes for the pupils from lowincome families, or there was even no choice at all in some of the observed schools.

Being rather a quick check-up than a presentable national investigation, the present study of the free lunch issue in public schools of Lithuania has highlighted some faulty practices, which seem discriminative and incompatible with the vision of a good sustainable school. It is a direct responsibility of the official founders of public schools to guarantee the observance of laws and the preoccupation to foster the best sustainable models of school life. No concept of "good school" could be realized without consistent efforts aimed at the improvement of school environment and constant care about children's welfare.

\section{Conclusions}

School meal is more than nutrition and shall be treated as an integral element of school life, providing healthy environment, sustainable schooling and personal dignity.

The data of the present research have revealed the deficiencies of quality service and children's rights infringements in some of Lithuanian public schools: no possibility to eat lunch for all pupils, besides pupils eligible for free lunch encounter some forms of discrimination because of limited or lacking opportunity for them to choose a dish, and discriminatory practice of separate queues for pupils from needy families.

The lack of attention to the common principles of the Children Rights and vital needs of the developing personality in the public school may become a serious obstacle to build social equality and sustainable schooling.

\section{Acknowledgment}

The authors would like to thank James E. Fisher, Ed. D. ERA/USA for reading and improving English of this article.

\section{References}

Belot, M., \& James, J. (2011). Healthy school meals and educational outcomes. Journal of Health Economics, 30 (3), 489-504. doi: 10.1016/j.jhealeco.2011.02.003.

Berg, B. L. (2007). Qualitative research methods for the social science. Long Beach: California State University. 
Bradshow, J., Hoelscher, P., \& Richardson, P. (2007). An index of child well-being in the European Union. Social Indicators Research, 80, 133-177. DOI: 10.1007/9781-4020-9304-3_16.

Bryman, A. (2012). Social research methods. New York: Oxford University Press.

Cohen, J., McCabe, L., Michelli, N. M., \& Pickeral, T. (2009). School climate: Research, policy, practice, and teacher education. Teachers College Record, 111(1), 180-213.

Committee on the Rights of the Child. (2013). General comment No. 15 (2013) on the right of the child to the enjoyment of the highest attainable standard of health (art. 24). UNICEF: Geneva, Switzerland. Retrieved May 20, 2016, from http://www.refworld.org/docid/51ef9e134.html

Comment of the Ombudsperson for Children's Rights of the Republic of Lithuania for the Report of the Republic of Lithuania on the Implementation of the United Nations Convention on the Rights of the Child in Lithuania in 2004-2008. Retrieved May 20, 2016, from http://www3.lrs.lt/docs2/EMLSKFCI.PDF

Communication from the Commission. EUROPE 2020. A strategy for smart, sustainable and inclusive growth. Brussels, 3.3.2010.COM (2010) 2020. Retrieved May 23, 2016, from http://ec.europa.eu/eu2020/pdf

Constantine, D. (2015). Lunch Lines. Inequitable cafeteria practices stigmatize lowincome students. Education Digest, 80(7), 13-16.

Convention on the Rights of the Child. (1989). Retrieved May 1, 2016, from http://www.ohchr.org/en/professionalinterest/pages/crc.aspx

Dewey, J. (2013). Demokratija ir ugdymas [Democracy and Development]. Klaipeda: Baltic Printing House.

Geros mokyklos koncepcija. [The concept of the good school]. (2015). Official Gazeta, $\mathrm{V}-1308$.

Jonutytė, I., Rupšienè, L., Šmitienè, G., Merfeldaite, O., Indrašienè, V., \& Valeckienè, D. (2009). Galimos diskriminacijos apraiškos bendrojo lavinimo mokykloje [Possible signs of discrimination in the comprehensive schools]. Retrieved May 1, 2016, from http://www.smm.lt/uploads/documents/kiti/Tyrimo $\% 20$ ataskaita $\% 20$ galimos\%20diskriminacijos\%20apraiskos_KU_2009.pdf

Finnish National Board of Education (2008). School meals in Finland. Investement in learning. Retrieved from http://www.oph.fi/download/47657_school_meals_in_ finland.pdf

Kupiainen, S., Hautamäki, J., \& Karjalainen, T. (2009). The Finnish education system and PISA. Retrieved May 5, 2016, from http://www.minedu.fi/export/sites/default/ OPM/Julkaisut/2009/liitteet/opm46.pdf

Lithuania's Progress Strategy “Lithuania 2030”. (2012). Retrieved May 6, 2016, from http://erawatch. jrc.ec.europa.eu/erawatch/opencms/information/country_pages/lt/ policydocument/policydoc_0005

Nilson, B. L. (2010). Teaching at its best. San Francisco:A Willey Imprint.

Patyčios Lietuvos mokyklose: problemos ir jų sprendimo būdai [Bullying in Lithuanian schools: Problems and Solutions]. Švietimo problemos analize. (2009), Nr. 11 (39).

Pukelis, K. (1998). Mokytojurengimas ir filosofines studijos [Teacher training and philosophical studies]. Kaunas: Versmè.

Räiha, T., Tossavainen, K., Turunen, H., Enkenberg, J., \& Kiviniemi, V. (2012). Effects of nutrition health intervention on pupils' nutrition knowledge and eating habits. 
Scandinavian Journal of Educational Research, 56(3), 277-294. doi: 10.1080/ 00313831.2011 .581688$.

Republic of Lithuania Law on Fundamentals of Protection of the Rights of the Child. (1996). Official Gazeta [Official Newspaper], 33-807.

Republic of Lithuania Law on Social Assistance for Pupils. (2006). Official Gazeta [Official Newspaper], X-686. Retrieved May 20, 2016, from https://www.ilo.org/ dyn/natlex/docs/ELECTRONIC/90167/103772/F227634370/LTU90167_Eng.pdf Scott, W. (2013). Developing the sustainable school: thinking the issues through. The Curriculum Journal, 24(2), 181-205. doi: 10.1080/09585176.2013.781375.

State Strategy for Education 2013-2020. (2013). Retrieved May 6, 2016, from http://www.smm.lt/web/lt/teisesaktai/tei/valstybine-svietimo-strategija_1

Storey, H. C., Pearce, J., Ashfield-Watt, P. L., Wood, L., Baines, E., \& Nelson, M. (2011). A randomized controlled trial of the effect of school food and dining room modifications on classroom behaviour in secondary school children. European Journal Of Clinical Nutrition, 65(1), 32-38. doi: 10.1038/ejcn.2010.227.

Szczepańska, E., Deka, M., \& Calyniuk, B. (2013). Studies to determine nutrition behaviour amongst middle school pupils living in the border areas of Poland and the Czech Republic. Roczniki Państwowego Zakładu Higieny [Annals of the National Institute of Hygiene], 64(3), 191-196.

The Basic Education Act (628/1998). (2010). Retrieved May 6, 2016, from https://www.finlex.fi/en/laki/kaannokset/1998/en19980628.pdf

Correspondence concerning this paper should be addressed to Brigita Kairiene, Assoc. Prof., Dr. Institute of Education and Social Work, Mykolas Romeris University, Ateities str.20, C-V-254, Vilnius, LT-08303, Lithuania.Email: b.kairiene@mruni.eu or

Andrius Sprindziunas, Institute of Philosophy and Humanities, Mykolas Romeris University, Ateities str. 20, C-V-502, Vilnius, LT-08303, Lithuania. Email: aspri@mruni.eu 